Since the above work was completed, two papers by $\mathrm{H}$. G. Callan have come to our attention ${ }^{7}$; he reports that nuclei from amphibian oocytes are permeable to low molecular weight solutes (up to tetranucleotides), but not to egg albumin, glycogen, acacia or soluble celluloses.

JoHN H. MaClendon L. R. BLINKS

Hopkins Marine Station,

Stanford University,

Pacific Grove,

California.

Jan. 3 .

'Granick, S., in "Photosynthesis in Plants", edited by Franck, T., and Loomis, W. E., 113 (Iowa State College Press, 1949). Schneider, W. C., and Hogeboom, G. H., Cancer Res., 11, 1 (1951).

${ }^{2}$ Mcclendon, J. H., thesis, University of Pennsylvania (1951).

${ }^{3}$ Stafford, H. A., thesis, University of Pennsylvania (1951).

${ }^{4}$ Harris, D. L., Biol. Bull., 85, 179 (1943).

${ }^{5}$ McClelland, C. P., and Bateman, R. L., Chem. and Enq. News, 23, 247 (1945).

${ }^{6}$ Couper, A., and Eley, D. D., J. Polymer Sci., 3, 345 (1948). Newton, F. B., Carbide and Carbon Chemicals Co. (personal communication).

${ }^{\prime}$ Callan, H. G., Exp. Cell Research, Supp., 1, 48(1949) ; Proc. Eighth Int. Cong. Genetics (supp. to Hereditas, 547 (1949)).

\section{Sodium Acetate Agar as a Sporulation Medium for Yeast}

THE formation of adequate numbers of 4-spored asci in yeasts is essential for genetical analysis, and, as spore viability decreasos with age, it is advisable to induce rapid sporulation and transfer spores as soon as possible to a nutrient medium containing sugar.

Adams $^{1}$ has obtained high yields of spores with baker's yeast by incubating for seven days on a sporulation medium consisting of 0.14 per cent anhydrous sodium acetate, 0.04 per cent dextrose and 2 per cent agar. I have tested various modifications of this formula on American 'Yeast Foam' (a strain of Saccharomyces cerevisioe); incubation of sporulation media, after inoculation, was restricted to $40-48 \mathrm{hr}$. at $25^{\circ} \mathrm{C}$. On a medium consisting of $0 \cdot 3-0.5$ per cent anhydrous sodium acetate $+1 \cdot 5$ per cent agar, $p \mathrm{H} \quad 6 \cdot 5-7 \cdot 0$ (sterilized for $20 \mathrm{~min}$. at $122^{\circ} \mathrm{C}$. ), 40 per cent sporulation (percentage of cells forming asci) has been recorded several times. Although sporulation is inferior to that recorded for the same yeast by Hartelius and Ditlevsen ${ }^{2}$ on gypsum (45 per cent) and cement ( 56 per cent), this is more than compensated by a higher proportion of 4 -spored asci : on the acetate medium, these constitute 12 per cent of the cell population (mean of twelve trials) compared with 8 per cent on cement ${ }^{2}$ and 4 per cent on gypsum ${ }^{2}$.

Trials with other yeasts have shown that sodium acetate agar, prepared as above, gives consistently high numbers of 4-spored asci after $48 \mathrm{hr}$. Thus, in several hybrids, up to 50 per cent of the cells have produced 4-spored asci. The introduction of this sporulation medium, therefore, should prove of great value in genetical studies on yeast.

R. R. FOWELI

Research and Development Department,

'Tho Distillers Co., Ltd.,

Great Burgh,

Epsom, Surrey.

${ }^{1}$ Adarns, A. M., Can. J. Res., C, 27, 179 (1949).

${ }^{2}$ Hartelius, V., and Ditlevsen, F., Nature, 168, 385 (1951),

\section{Coupling Azo Dye Methods for Histochemical Demonstration of Alkaline Phosphatase}

THE coupling azo dye methods of Menten, Junge and Green ${ }^{1}$, and of Manheimer and Seligman ${ }^{2}$, have generally been found insensitive and unsatisfactory for the demonstration of alkaline phosphatase. The recent improvement of the method by Gomori ${ }^{3}$, using sodium $\alpha$-naphthyl phosphate, has overcome some of their disabilities. We have confirmed that this substrate is the best available, but find that with acetonefixed paraffin sections the method is still insensitive and useful only for the demonstration of sites of high enzyme activity.

If brief cold formalin fixation $\left(4^{\circ}, 8-16 \mathrm{hr}\right.$.) is substituted, and $10-15-\mu$ frozen sections, the method becomes as sensitive as any so far published. Preservation of enzyme is good, fixation artefacts few and enzyme diffusion negligible. Nuclear staining, reported absent by Gomori ${ }^{3}$ and Novikoff ${ }^{4}$, we have often observed in paraffin but never in frozen sections. Using cold formalin-fixed sections, the most important single factor becomes the choice of a suitable diazonium salt for coupling at an alkaline $p H$.

We have tested a number of stable diazotates thought likely to be suitable on theoretical grounds as coupling agents in the alkaline phosphatase method. Cold formalin $\left(4^{\circ}\right)$ fixed $(16-\mathrm{hr}$.) frozen sections (15 $\mu$ thick) of rat kidney were used, in veronal acetate buffer at $p \mathrm{H} 9 \cdot 2$. A note was made of (1) the speed of the reaction, (2) the rate of decomposition of the diazonium salt, (3) the colour of the final product, and (4) the type of precipitate. The results, in the case of nine stable diazotates, appear in the accompanying table.

\begin{tabular}{|c|c|c|c|c|}
\hline Diazonium salt of & Inhibition & $\begin{array}{l}\text { Decom- } \\
\text { position }\end{array}$ & Colour & $\begin{array}{l}\text { Diffuse or } \\
\text { particulate }\end{array}$ \\
\hline $\begin{array}{l}\text { 1. 1-Amino-anthra- } \\
\text { quinone }\end{array}$ & $+t+$ & +++ & $\begin{array}{l}\text { Brick- } \\
\text { red }\end{array}$ & Diffuse \\
\hline $\begin{array}{l}\text { 2. 4. Benzoylamino- } \\
2: 5 \text { dimethoxy- } \\
\text { aniline }\end{array}$ & & + & Black & Particulate \\
\hline 3. $p$-Nitroaniline & $++t$ & ++ & Brick- & Particulate \\
\hline 4. 4-Chloro-2-nitro- & +++ & + & $\begin{array}{l}\text { Rose- } \\
\text { red }\end{array}$ & Particulate \\
\hline $\begin{array}{l}\text { 5. } 2: 5 \text { Dichlor- } \\
\text { aniline }\end{array}$ & $+t$ & ++ & $\begin{array}{l}\text { Red- } \\
\text { brown }\end{array}$ & Particulate \\
\hline $\begin{array}{l}\text { 6. o-Dianisidine } \\
\text { 7. 4-Chloro-o-anis- }\end{array}$ & + & $\begin{array}{c}+++t \\
++\end{array}$ & Black & $\begin{array}{l}\text { Diffuse } \\
\text { Particulate }\end{array}$ \\
\hline 8. 5-Nitro-o-anis- & ++ & & Red- & Diffuse \\
\hline $\begin{array}{l}\text { 9. 5-(Chloro-o-tolu- } \\
\text { idine }\end{array}$ & + & nisil to + & Brown & Particulate \\
\hline
\end{tabular}

Degrees of inhibition are registered from + to ++++ , the former indicating almost complete absence. Similarly, in the case of decomposition, one + means practically no visible staining of the background structures. The reference 'particulate' means that the
dye particles were large enough to be clearly visible with the $2 / 3$ dye particles were large enough to be clearly visible with the $2 / 3$
objective; diffuse means a particle size not appreciable at this magnification.

The question of diffusion of the reaction product was controlled by incubating two sections face to face, one inactivated by heat $\left(15 \mathrm{~min} . / 90^{\circ}\right)$ and Lugol's iodine solution (15 min.), the other untreated. No diffusion of the reaction product was detected with any of the salts within the limits $(100 \mu)$ of the distance between the two sections, provided that the concentration of the diazonium salt was sufficiently high. The optimum concentration for all these salts was found to be in the region of $1 \mathrm{mgm}$. per $\mathrm{ml}$. substrate solution. With stronger concentrations, in the region of $5 \mathrm{mgm}$. per $\mathrm{ml}$., inhibition was excessive, 